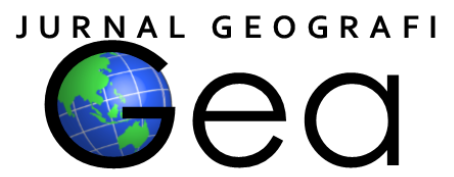

\title{
PENERAPAN METODE ANALITICAL HIERARCHY PROCESS (AHP) DALAM PEMBUATAN ZONA NILAI TANAH
}

\author{
Adkha Yulianandha Mabrur ${ }^{1}$ \\ ${ }^{1}$ Prodi Teknik Geodesi, Institut Teknologi Nasional Malang \\ ${ }^{1}$ adkha.yulianandha.mabrur@lecturer.itn.ac.id
}

\begin{abstract}
Land is a support for one's life, the need for land is increasing. This is due to the development of the function of land use. People's assessment of a piece of land will be very different, because land has several different dimensions and sizes. Therefore, in assessing land needs a special expertise. The land valuation model used by BPN for making Land Value Zone (ZNT) maps is a mass land valuation model using a market comparison procedure in one zone. The level of knowledge and experience of the evaluator in this valuation model influences the results of zones and valuations that are more subjective. Therefore the Analytical Heirarchy Procurement (AHP) method was chosen to be able to approach magnitudes or measurements more objectively and to eliminate subjectivity. Through calculations with AHP, the criteria for determining the value of land are obtained, namely accessibility with a weighting of 58\%, 14\% land use, and $28 \%$ public facilities. From the calculation of the importance weight using AHP applied to the spatial analysis so that it can be grouped into one area with the same weight by assuming that areas that have similar weights have almost the same land value.
\end{abstract}

Keywords: Land Value Zone, Analitical Heirarchy Process (AHP), GIS

\begin{abstract}
ABSTRAK
Tanah merupakan suatu penunjang kehidupan seseorang, kebutuhan akan tanah semakin lama semakin meningkat. Hal ini dikarenakan berkembangnya fungsi dari pemanfaatan tanah. Penilaian orang atas sebidang tanah akan menjadi sangat berbeda, karena tanah memiliki beberapa dimensi dan ukuran yang berbeda-beda pula. Oleh karena itu dalam menilai tanah perlu suatu keahlian tersendiri. Model penilaian tanah yang digunakan oleh BPN untuk pembuatan peta Zona Nilai Tanah (ZNT) adalah model penilaian tanah secara masal dengan menggunakan prosedur perbandingan pasar dalam satu zona. Tingkat pengetahuan dan pengalaman penilai pada model penilaian ini berpengaruh terhadap hasil zona dan penilaian yang lebih bersifat subjektif. Oleh karena itu metode Analitical Heirarchy Proccess (AHP) dipilih untuk dapat mendekatkan besaran atau ukuran secara lebih objektif dan untuk mengeliminasi subjektifitas. Melalui perhitungan dengan AHP maka diperoleh kriteria faktor penentu nilai tanah yaitu aksebilitas dengan bobot kepentingan 58\%, penggunaan lahan 14\%, dan fasilitas umum 28\%. Dari perhitungan bobot kepentingan menggunakan AHP diaplikasikan kedalam analisi spasial sehingga dapat kelompokan kedalam satu area dengan bobot yang sama dengan mengasumsikan bahwa area yang mempunyai kemiripan bobot maka mempunyai nilai tanah yang hampir sama.
\end{abstract}

Kata kunci: Zona Nilai Tanah (ZNT), Analitical Heirarchy Process (AHP), SIG 


\section{PENDAHULUAN}

Tanah merupakan salah satu penunjang yang membantu kehidupan semua mahluk hidup yang ada di bumi tidak terkecuali manusia. Bagi manusia tanah mempunyai fungsi pokok yaitu sebagai tempat kelangsungan hidup (sebagai tempat tinggal dan investigasi). Dewasa ini seiring dengan semakin majunya perkembangan manusia dalam segala hal berpengaruh pada arti dan fungsi tanah tersebut. Oleh karena itu kebutuhan akan ketersediaan dan permintaan tanah menjadi semakin meningkat dari waktu ke waktu. Akibat dari permasalahan itu terjadi keterbatasan tersedianya tanah karena permintaan tanah yang meningkat lebih besar dari tanah yang dapat disediakan, sehingga mendorong kenaikan nilai tanah yang tak terkendali (Sukanto dan Karseno, 1994).

Penilaian orang atas sebidang tanah akan menjadi sangat berbeda, karena tanah memiliki beberapa dimensi dan ukuran yang berbeda-beda pula. Oleh karena itu dalam menilai tanah perlu suatu keahlian tersendiri. Selain membutuhkan pengalaman, penilaian tanah juga membutuhkan pengetahuan yang memadai tentang prinsip-prinsip penilaian, teknik pendekatan dalam penilaian, faktorfaktor yang berpengaruh secara langsung atau tidak langsung dan pengetahuan tentang teknik atau metode yang dapat dipakai untuk mempermudah estimasi nilai tanah (Damayanti dan Syah, 2009)

Model penilaian tanah yang digunakan oleh BPN untuk pembuatan peta Zona Nilai Tanah (ZNT) adalah model penilaian tanah secara masal dengan menggunakan prosedur perbandingan pasar dalam satu zona. Hal ini memungkinkan nilai tanah antar bidang tersebut sama walaupun memiliki lokasi dan aksesibilitas yang berbeda. Pembuatan zona awal nilai tanah di BPN belum memiliki standar baku termasuk yang sudah diatur pada SE-25/PJ.6/2006 Tata Cara Pembentukan/Penyempurnaan ZNT/NIR. Tahapan pembuatan zona awal ada kecenderungan petugas survei yang bebas mengintegrasikan setiap variable-variabel yang diinginkan dan seberapa besar prosentase penyesuainya. Tingkat pengetahuan dan pengalaman penilai akan berpengaruh terhadap hasil zona dan penilaian yang lebih bersifat subjektif.

Memperhatikan alasan tersebut solusinya adalah dilakukan perbaikan prosedur pembuatan zona nilai tanah dengan menggunakan Analytical Hierarchy Process (AHP) atau Analisis Proses Berjenjang. Metode AHP merupakan proses analisis yang menggunakan pendekatan Multicriteria Decision Analysis (MCDA). AHP diharapkan dapat mendekatkan besaran atau ukuran secara lebih objektif dan untuk mengeliminasi subjektifitas.

Studi kasus dilakukan di Kecamatan Sewon. Kecamatan Sewon merupakan salah satu kecamatan di Kabupaten Bantul yang tergolong paling berkembang, dengan ditunjukan dengan aksesibilitas yang bagus, banyak terdapat kampus, sekolah dan fasilitas umum yang lengkap serta letaknya yang berbatasan langsung dengan Kota Yogyakarta. Kecamatan Sewon ini juga merupakan salah satu tujuan pemukiman di kawasan pinggiran Kota Yogyakarta. Hal ini terbukti dari meningkatnya penggunaan lahan, terutama untuk pembangunan perumahan. Dengan adanya peningkatan penggunaan lahan dari tahun ke tahun akan berdampak pada tingginya jumlah permintaan akan lahan yang mengakibatkan meningkatnya transaksi jual beli tanah didaerah tersebut sehingga akan berpengaruh dengan meningkatnya nilai tanah pada daerah tersebut. Oleh karena itu penulis akan membahas mengenai pemetaan Zona Nilai Tanah dengan metode Analytical Hierarchy Process (AHP) dengan studi kasus di Kecamatan Sewon, Kabupaten Bantul, Provinsi D.I. Yogyakarta.

\section{METODE PENELITIAN}

Metode yang digunakan dalam penelitian ini adalah metode kuantitatif yang dilakukan secara sistematis, terstruktur, serta terperinci. Pada pelaksanaaannya, metode riset ini fokus pada penggunaan angka, tabel, grafik, dan diagram untuk menampilkan hasil data/ informasi yang diperoleh dengan menggunakan Analytical Hierarchy Process (AHP). Menurut Saaty (1992) AHP merupakan suatu model pendukung keputusan yang menguraikan masalah multikriteria yang kompleks menjadi bentuk hierarki. 

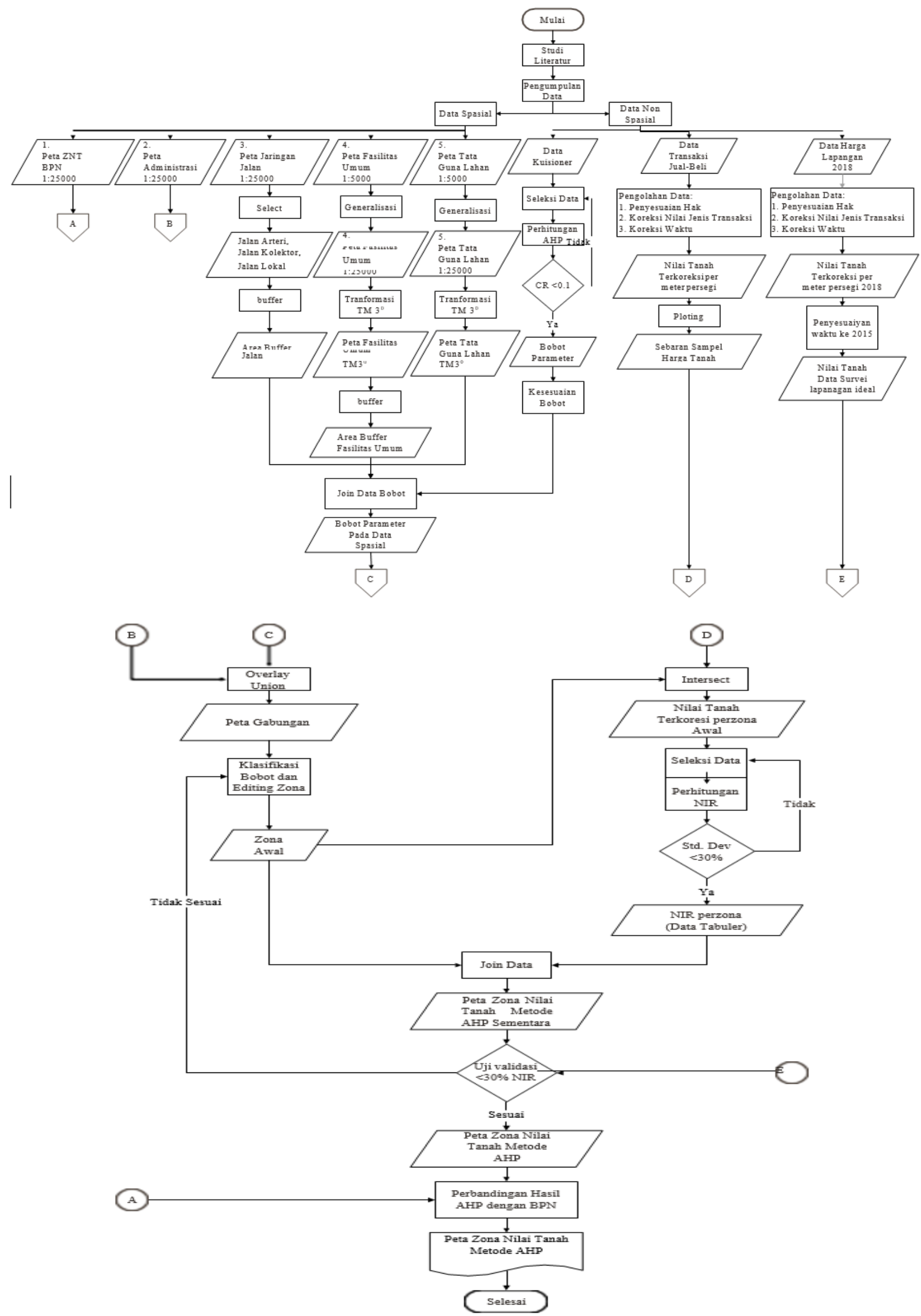

Gambar 1. Metodologi Penelitian 
Hirarki merupakan suatu bentuk terstruktur dan sistematis dari berbagai permasalah kompleks. Menurut Saaty data utama model AHP merupakan persepsi manusia yang diangap mengetahui benarbenar permasalahanya (expert).

Menurut Achsin (2011) AHP berguna untuk mendekati kriteria yang bersifat kuantitatif maupun kualitatif, AHP berprinsip bahwa perasaan, intuisi, penginderaan, dan pengalaman seseorang, minimal sama nilainya dengan data yang digunakan. Dengan memasukkan "fungsi psikologis", AHP dapat menutupi kelemahan utama metode pengambilan keputusan yang bersifat kualitatif.

Secara garis besar, tahapan pelaksanaan ini menjelaskan tentang diagram alir penelitian yang dirangkum sebagai berikut :

Studi literatur dan pengumpulan data: Pada tahapan ini, hal yang dilakukan adalah: Mengumpulkan materi yang akan digunakan parameter dalam penelitian dan menentukan parameter dalam penelitian ini, Materi tentang Analitical Hierarchy Process, Nilai Indeks Rata-rata Tanah, Zona Nilai Tanah, dan materi lain yang berkaitan dengan Penelitian ini.

Pengumpulan data: Pada tahapan ini, hal yang dilakukan adalah mengumpulan data yang digunakan dalam penelitian berupa data spasial dan data non spasial.

\section{Data spasial}

Peta digital, jaringan jalan dan Zona Nilai Tanah Kecamatan Sewon dari kantor Badan Pertanahan Nasional Kab. Bantul, dengan format shapefile (*.shp) dengan datum WGS 1984 dan sistem proyeksi Transferse Mercator $3^{0}$ zone $49-1$ s

Peta digital tata guna lahan, administrasi, dan persebaran fasilitas umum kecamatan sewon dari kantor BAPPEDA Kab. Bantul, dengan format shapefile (*.shp) dengan datum WGS 1984 dan sistem proyeksi Universal Transferse Mercator zone 49s. persebaran fasilitas umum diluar kecamatan sewon yang masih mempengaruhi nilai tanah di kecamatan sewon juga dipilih.

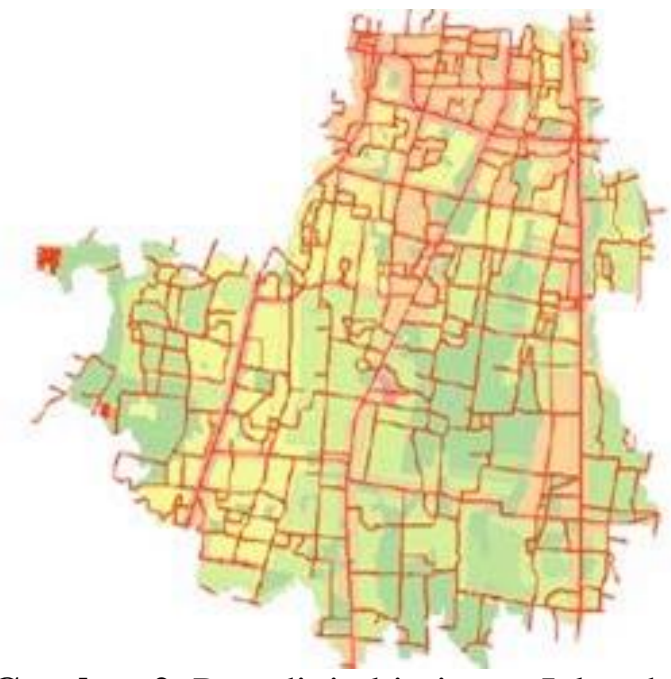

Gambar 2. Peta digital jaringan Jalan dan Zona Nilai Tanah Kec. Sewon

\section{Data non-spasial}

Data non-spasial pada penelitian ini meliputi: Data kuisioner hasil survey lapangan berkaitan dengan AHP. Pada metode AHP digunakan metode kuisioner terbuka dengan mengatur pertanyaan sedemikian rupa sehingga mempertimbangkan jawaban yang dapat dikonversi sesuai dengan skala AHP, sampel responden yang dipilih dalam penelitian ini adalah responden yang paham tentang permasalahan nilai tanah, oleh karena itu responden yang dipilih antaralain : akademisi yang berkopenten dalam penilaian tanah, pemerintah kecamatan dan Pemerintah desa yang berkopen dalam penilaian tanah, staff ahli BPN dalam pemetaan ZNT, Staff ahli penilaian tanah oleh Dinas Pendapatan Pengelolaan Keuangan dan Aset, Staff ahli penilaian tanah dari kantor PPAT, broker/calo tanah, dan lain-lain. Sampel data transaksi jual beli tanah di Kecamatan Sewon dalam kurun waktu 2014 - 2015 dari Kantor BPN Kab.Bantul yang bersumber dari survey lapangan oleh petugas BPN, data transaksi dari Kantor PPAT dan Camat. Data harga tanah survey lapanagan diperoleh dari hasil wawancara nilai tanah oleh berbagai narasumber, narasumber yang dipilih dalam penelitian ini antara lain: Penjual ataupun pembeli property, Petugas Pemerintahan Desa dalam hal ini adalah Kasie Pemerintahan, developer, dan Broker/Calo Tanah. Pada penelitian ini diperoleh 21 data harga tanah yang tersebar diseluruh kecamatan sewon. 


\section{HASIL DAN PEMBAHASAN}

Hasil Analisis Parameter Nilai Tanah 1. Hasil Bobot Kriteria Utama (Level 1): Kriteria utama pada factor penentu nilai tanah terdiri dari 3 kriteria yaitu, aksebilitas, penggunaan lahan, dan fasilitas umum. Hasil pembobotan pada kriteria utama setelah dilakukan perhitungan pada uraian sebelumya sehingga didapatkan hasil sesuai pada tabel 1 .

Tabel 1. Bobot kriteia utama factor penentu nilai tanah

\begin{tabular}{|c|c|c|}
\hline Parameter & Bobot & CR \\
\hline Aksebilitas & 0.579 & \\
\cline { 1 - 2 } Penggunaan Lahan & 0.137 & \multirow{2}{*}{0.056} \\
\cline { 1 - 2 } Fasilitas Umum & 0.284 & \\
\hline
\end{tabular}

Berdasarkan hasil perhitungan AHP, nilai CR yang diperoleh adalah sebesar 0.056, maka syarat perhitungan hasil bobot pada kriteria utama AHP dipenelitian ini sudah memenuhi syarat dari prinsip AHP Logical Consistency yaitu CR $<0.1$ Hasil Bobot Sub-Kriteria (Level 2): Sub-kriteria merupakan turunan dari kriteria utama (level 1), kriteria utama terdiri dari 3 Kriteria, pada setiap kriteria utama terdiri dari beberapa sub-kriteria. Berikut merupakan hasil bobot pada setiap sub-kriteria: Bobot sub-kriteria Aksebilitas Pada kriteria aksebilitas terdiri dari 3 (tiga) sub- kriteria yaitu Jalan Arteri, Jalan Kolektor, dan Jalan Lokal. Berikut merupakan bobot pada sub-kriteria aksebilitas dapat dilihat sesuai tabel 2.

Tabel 2. Bobot Sub-kriteria Aksebilitas

\begin{tabular}{|l|c|c|}
\hline \multicolumn{1}{|c|}{ Parameter } & Bobot & CR \\
\cline { 1 - 2 } Jalan Arteri & 0.682 & \multirow{2}{*}{0.095} \\
\cline { 1 - 2 } Jalan Kolektor & 0.25 & \\
\cline { 1 - 2 } Jalan Lokal & 6.74 & \\
\hline
\end{tabular}

Berdasarkan hasil perhitungan AHP pada tabel 2, nilai CR yang diperoleh adalah sebesar 0.095, maka syarat perhitungan hasil bobot pada Sub-Kriteria Aksebilitas sudah memenuhi syarat dari prinsip AHP Logical Consistency yaitu $\mathrm{CR}<0.1$.

2. Bobot sub-kriteria Penggunaan Lahan. Pada kriteria penggunaan lahan terdiri dari 6 (enam) sub-kriteria yaitu Pemukiman, Industri, Perdagangan dan jasa, Kebun,
Sawah, dan Tegalan. Berikut merupakan bobot pada sub-kriteria penggunaan lahan dapat dilihat sesuai tabel 3.

Tabel 3. Bobot Sub-kriteria Penggunaan Lahan

\begin{tabular}{|c|c|c|}
\hline Parameter & Bobot & CR \\
\hline Pemukiman & 0.16 & \\
\cline { 1 - 2 } Industri & 0.267 & \\
\cline { 1 - 1 } $\begin{array}{c}\text { Perdaganagan dan } \\
\text { Jasa }\end{array}$ & 0.429 & \\
\cline { 1 - 2 } Kebun & 0.046 & \\
\hline Sawah & 0.053 & \\
\hline Tegalan & 0.046 & \\
\hline
\end{tabular}

Berdasarkan hasil perhitungan AHP pada tabel 3, nilai $\mathrm{CR}$ yang diperoleh adalah sebesar 0.031 , maka syarat perhitungan hasil bobot pada sub-kriteria penggunaan lahan sudah memenuhi syarat dari prinsip AHP Logical Consistency yaitu CR $<0.1$

3. Bobot sub-kriteria Fasilitas Umum. Pada kriteria fasilitas umum terdiri dari 4 (empat) sub-kriteria yaitu Perdagangan, Perkantoran, Fasilitas Pendidikan dan Fasilitas Kesehatan. Berikut merupakan bobot prioritas pada subkriteria fasilitas umum dapat dilihat sesuai tabel 4.

Tabel 4. Bobot sub-kriteria Fasilitas Umum

\begin{tabular}{|c|c|c|}
\hline Parameter & Bobot & CR \\
\hline Perdagangan & 0.16 & \\
\cline { 1 - 2 } Perkantoran & 0.267 & \multirow{2}{*}{0.046} \\
\cline { 1 - 2 } Fasilitas Pendidikan & 0.429 & \\
\hline Fasilitas Kesehatan & 0.046 & \\
\hline
\end{tabular}

Berdasarkan hasil perhitungan AHP pada tabel 4 , nilai $C R$ yang diperoleh adalah sebesar 0.046 , maka syarat perhitungan hasil bobot pada sub-kriteria fasilitas umum sudah memenuhi syarat dari prinsip AHP Logical Consistency yaitu CR $<0.1$

4. Bobot Sub-sub-Kriteria (Level 3): Pada penelitaian ini sub-sub-kriteria merupakan level terendah dari susunan hierarki factor penentu nilai tanah. Sub-subKriteria pada penelitian ini merupakan turunan Sub-kriteria dari fasilitas pendidikan yang terdiri dari beberapa elemen Sub-subKriteria antara lain: Universitas/perguruan tinggi, Sekolah Menengah Atas, Sekolah Menegah Pertama, Sekolah Dasar. Berikut merupakan pembobotan prioritas dalam satu 
level Sub-sub- Kriteria yang sudah dilakukan perhitungan pada uraian sebelumnya pada tabel 5 .

Berdasarkan hasil perhitungan AHP pada tabel 5,nilai CR yang diperoleh adalah sebesar 0.044, maka syarat perhitungan hasil bobot pada sub-sub-kriteria fasilitas pendidikan sudah memenuhi syarat dari prinsip AHP Logical Consistency yaitu CR < 0.1 .

Untuk memenuhi prinsip AHP Comparative judges bobot elemen berpasang dalam satu level berhubungan dengan level diatasnya, maka bobot keseluruhan hasil dari perhitungan ahp disajikan pada tabel 6 .

Tabel 5. Bobot prioritas Sub-sub-kriteria Fasilitas Pendidikan

\begin{tabular}{|c|c|c|}
\hline Parameter & Bobot & CR \\
\hline Universitas & 0.602 & \\
\cline { 1 - 2 } SM A & 0.187 & \multirow{2}{*}{0.044} \\
\cline { 1 - 2 } SM P & 0.155 & \\
\hline SD & 0.057 & \\
\hline
\end{tabular}

Tabel 6. Hasil bobot akhir parameter

\begin{tabular}{|c|c|c|c|c|c|c|}
\hline $\begin{array}{c}\text { Kriteria } \\
\text { Utama }\end{array}$ & Sub-Krite ria & $\begin{array}{l}\text { Sub-sub- } \\
\text { Krite ria }\end{array}$ & $\begin{array}{c}\text { Bobot } \\
\text { Krite ria }\end{array}$ & $\begin{array}{c}\text { Bobot } \\
\text { Sub- } \\
\text { Krite ria } \\
\end{array}$ & $\begin{array}{c}\text { Bobot } \\
\text { Sub- sub } \\
\text { Krite ria } \\
\end{array}$ & $\begin{array}{l}\text { Bobot } \\
\text { Akhir }\end{array}$ \\
\hline \multirow{3}{*}{ Aksebilitas } & Jalan Arteri & \multirow{3}{*}{-} & \multirow{3}{*}{0.58} & 0.395 & - & 0.395 \\
\hline & Jalan Kolektor & & & 0.145 & - & 0.145 \\
\hline & Jalan Lokal & & & 0.039 & - & 0.039 \\
\hline \multirow{6}{*}{$\begin{array}{l}\text { Penggunaan } \\
\text { Lahan }\end{array}$} & Pemukiman & \multirow{6}{*}{-} & \multirow{6}{*}{0.14} & 0.022 & - & 0.022 \\
\hline & Industri & & & 0.036 & - & 0.036 \\
\hline & $\begin{array}{c}\text { Perdagangan dan } \\
\text { Jasa }\end{array}$ & & & 0.059 & - & 0.059 \\
\hline & Kebun & & & 0.006 & - & 0.006 \\
\hline & Sawah & & & 0.007 & - & 0.007 \\
\hline & Tegalan & & & 0.006 & - & 0.006 \\
\hline \multirow{7}{*}{$\begin{array}{l}\text { Fasilitas } \\
\text { Umum }\end{array}$} & Perdagangan & \multirow{3}{*}{-} & \multirow{7}{*}{0.28} & 0.142 & - & 0.142 \\
\hline & Perkantoran & & & 0.021 & - & 0.021 \\
\hline & Fasilitas Kesehatan & & & 0.045 & - & 0.045 \\
\hline & \multirow{4}{*}{$\begin{array}{c}\text { Fasilitas } \\
\text { Pendidikan }\end{array}$} & $\begin{array}{c}\text { Universita } \\
\mathrm{s} \\
\end{array}$ & & \multirow{4}{*}{0.077} & 0.046 & 0.046 \\
\hline & & SMA & & & 0.014 & 0.014 \\
\hline & & SMP & & & 0.012 & 0.012 \\
\hline & & $\mathrm{SD}$ & & & 0.004 & 0.004 \\
\hline \multicolumn{3}{|c|}{ Total } & 1 & 1 & 0.077 & 1 \\
\hline
\end{tabular}

Berdasarkan tabel 6 faktor penentu nilai tanah yang paling berpengaruh adalah jalan arteri yaitu sebesar 0.395 , dari hasil tersebut berarti bahwa pada area disekitar jalan arteri dipilih sebagai factor penentu nilai tanah paling tinggi menurut responden dibandingkan dengan factor penentu nilai tanah lainya. Sedangkan factor penentu nilai tanah yang paling rendah bobotnya adalah area disekitar Sekolah Dasar yaitu sebesar 0.004. Akan tetapi tidak dapat diartikan bahwa area disekitar Sekolah Dasar memiliki harga yang rendah, karena factor penentu nilai tanah yang lain yang masuk dalam area sekitar Sekolah Dasar juga perlu diperhitungkan. Hal tersebut juga berlaku pada faktor-faktor penentu nilai tanah yang lain.

\section{Zona Awal}

Zona awal pada penelitian ini dibentuk dari hasil pengabungan area di kelas yang sama pada hasil klasifikasi bobot akhir nilai perhitungan metode AHP. Dimaksutkan bahwa dikelas yang sama mempunyai kemiripan faktor penentu nilai tanah dan mempinyai indikasi nilai tanah mirip selain itu juga mempertimbangkan sebaran harga jual-beli tanah terkoreksi yang sudah diplot pada peta kerja. Zona Awal dilakukan dengan menambah attribute pada hasil klasifikasi dengan nama AA sampa dengan BD sesuai pada peraturan yang berlaku, sehingga hasil zona awal dikecamatan sewon terdapat 30 jenis zona dibentuk dari kemiripan bobot dari analisi spasial terhadap parameter fator penentu nilai tanah dan persebaran nilai tanah 
dari data transaksi jual-beli terkoreksi. Berikut merupakan hasil dari Zona Awal pada gambar 3

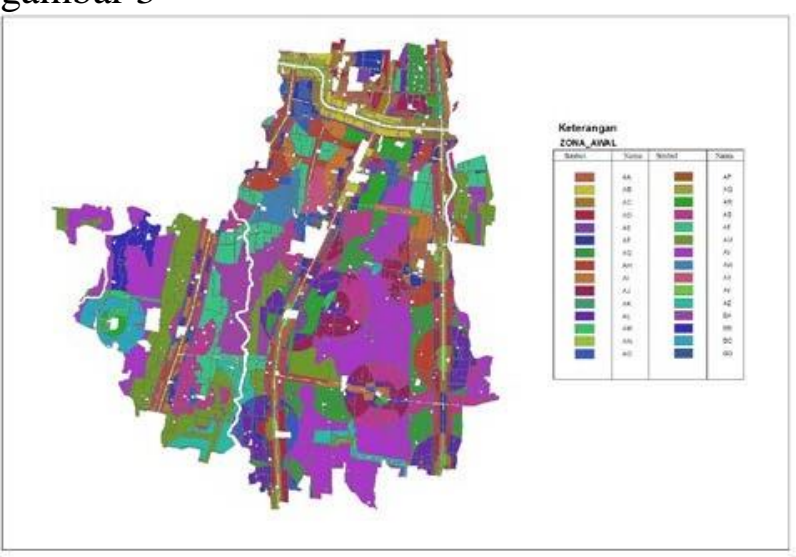

Gambar 3. Peta digital Zona Awal

\section{Nilai Indeks Rata-rata (NIR)}

Nilai indeks rata-rata pada penelitian ini dihitung dari rata-rata nilai transaksi jualbeli terkoreksi atau nilai ideal pada setiap zona awal, dengan syarat standar deviasi kurang dari $30 \%$ dari rata-ratanya. Berikut merupakan hasil perhitungan NIR pada tabel 7.

Tabel 7. Hasil perhitungan NIR

\begin{tabular}{|c|c|c|c|}
\hline NO & $\begin{array}{c}\text { Zona } \\
\text { awal }\end{array}$ & NIR & $\begin{array}{c}\text { standard } \\
\text { deviasi } \\
(\%)\end{array}$ \\
\hline 1 & AS & 343735 & 25.72 \\
\hline 2 & AQ & 1365865 & 20.9 \\
\hline 3 & AR & 441133 & 20.77 \\
\hline 4 & AL & 280707 & 20.11 \\
\hline$\cdots$ & $\cdots$ & $\cdots$ & $\cdots$ \\
\hline$\cdots$ & $\cdots$ & $\cdots$ & $\cdots$ \\
\hline$\cdots$ & $\cdots$ & $\cdots$ & $\cdots$ \\
\hline 30 & BD & 2333973 & 0.001 \\
\hline
\end{tabular}

Pada tabel 7 terdapat 30 Zona Awal dengan keseluruhan NIR yang dihasilkan, strandar deviasinya kurang dari $30 \%$ dari rata-ratan nilai tanah dalam satu zona. Standard deviasi terbesar terdapat pada zona AS yaitu sebesar $25.72 \%$ dari rata-ratanya sehingga pada zona AS terjadi penyimpangan terbesar daripada zona lain pada setiap data transaksi terhadap data transaksi rata-rata di zona tersebut. Sedangkan strandar deviasi terkecil terkecil terjadi pada zona BD yaitu sebesar $0.001 \%$, sehingga pada zona 30 rata-rata penyimpangan setiap data transaksi terhadap rata-rata data transaksi dizona tersebut terkecil.

Peta Zona Nilai Tanah Kecamatan Sewon metode AHP: Berikut merupakan hasil dari peta ZNT Kecamatan Sewon dengan Metode AHP dapat dilihat pada gambar 4.

Peta ZNT metode AHP kecamatan sewon sesuai gambar 4.7 diklasifikasikan menjadi 6 kelas rentang harga, kelas dengan nilai tanah tertinggi yaitu lebih dari 1 juta rupiah dengan disimbolkan dengan warna merah. Kelas dengan nilai paling rendah adalah kurang dari 250 ribu rupiah dengan simbol warna hijau. Dikecamatan sewon terdapat tanah milik pemerintah dan tidak dilakukan penilaian dengan disimbolkan pada peta dengan simbol putih.

Nilai tanah tinggi cenderung berada disekitar aksebilitas hal ini sesuai dengan perhitungan bobot mengunakan AHP bahwa faktor yang paling mempengaruhi nilai tanah adalah aksebilitas hal ini dibuktikan pada peta zona nilai tanah meteode AHP area disekitar jalan arteri mempunyai nilai >1juta rupiah. Pada area yang terdapat fasilitas umum maka nilai tanah disekitarnya mempunyai nilai yang tinggi tetapi lebih rendah daripada aksebilitas, hal ini dibuktikan pada area disekitar Pasar Ngoto, disekitar Balai Desa Bangunharjo dan SD Ngoto dengan lokasi yang saling berdekatan mempunyai nilai tanah antara 500ribu - 750ribu, kecuali di area dekat dengan jalan kolektor dengan nilai tanah $>$ juta rupiah. Pada peta ZNT metode AHP nilai terendah cenderung pada area persawahan yang tidak dilalaui oleh aksebilitas jalan yang termasuk parameter penentu nilai tanah dan jauh dari lokasi fasilitas umum, sehingga mempunyai bobot yang kecil hal ini berbanding lurus dengan nilai tanah peta ZNT AHP yang bernilai rendah yaitu $<250$ ribu rupiah.

Pada Peta Zona Nilai Tanah pada gambar 4.7 dapat diketahui sebaran zonasi nilai tanah di kecamatan sewon tahun 2015. Peta Zona Nilai Tanah hasil dari penelitian ini dapat digunakan untuk tahun-tahun kedepan, dengan mengasumsikan peningkatan nilai tanah berdasarkan pada Keputusan Direktur 
Jendral Pajak Nomor: KEP.533/PJ.6/2000, dengan klasifikasi penyesuaian nilai merujuk pada SE-55/PJ.6/1999. Besaran penyesuaian untuk 1-2 tahun kedepan nilai ditambahkan dengan $12 \%$ dari ZNT, untuk penyesuaian 2-3

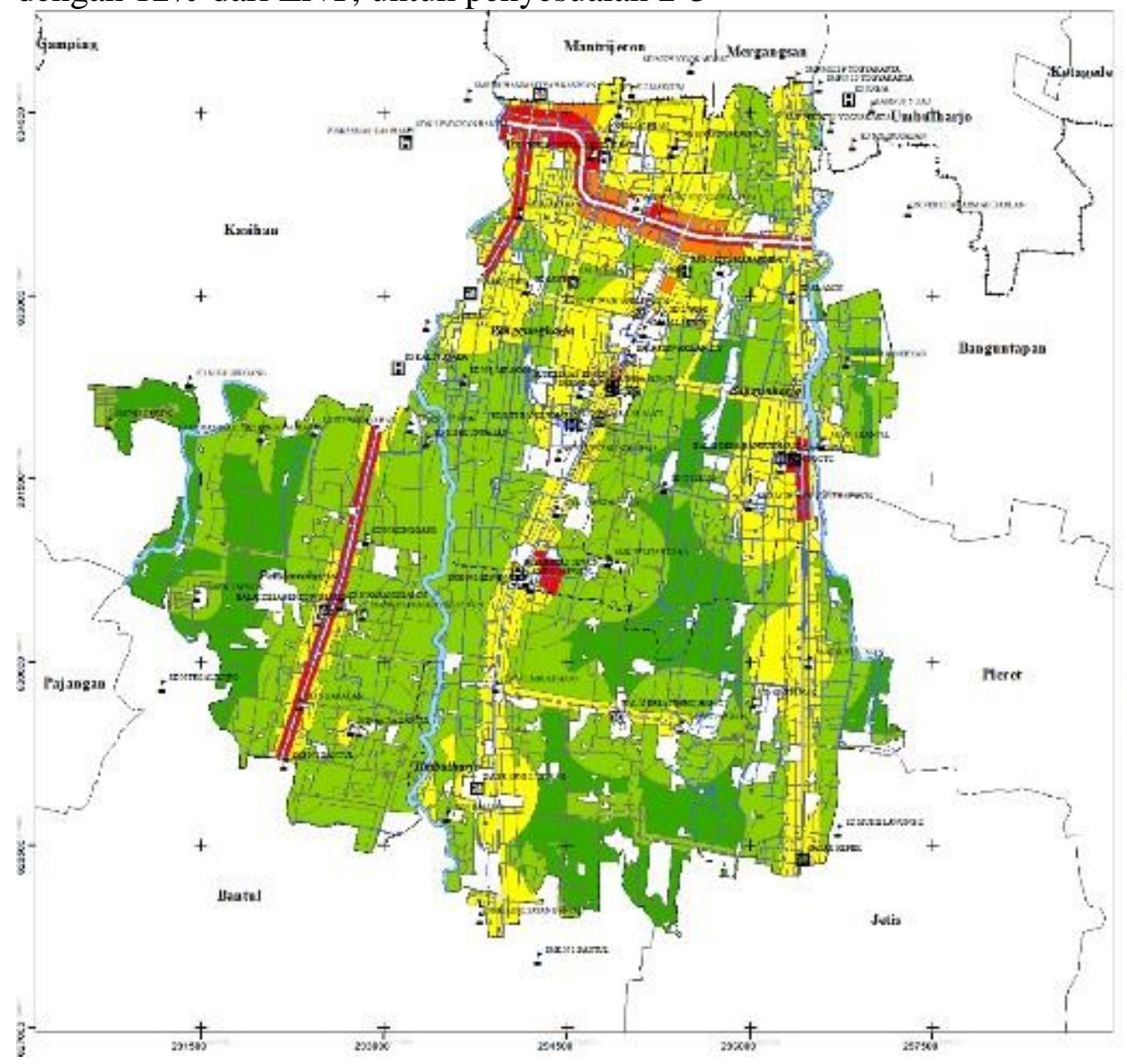

tahun kedepan ditambahkan $20 \%$ dari ZNT, dan untuk 3-6 tahun ditambahkan dengan $28 \%$ dari ZNT.

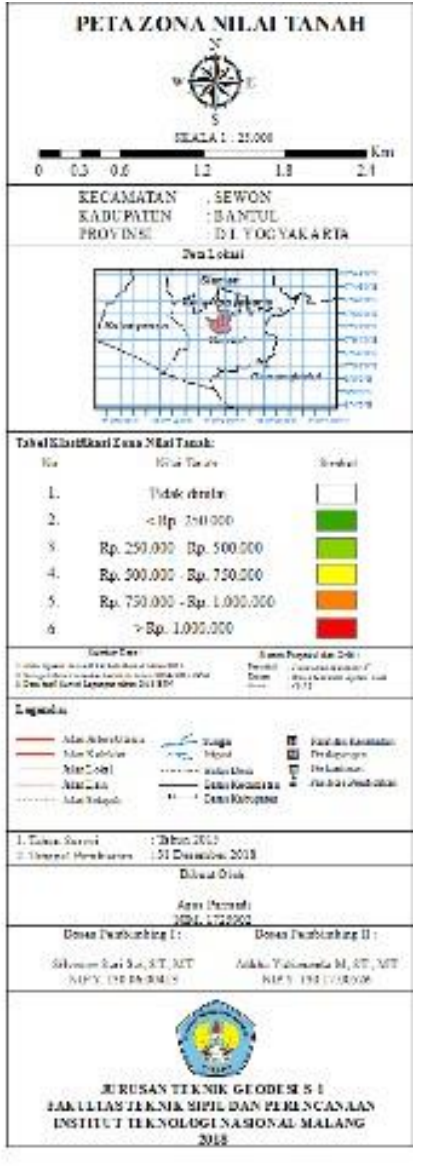

\section{Gambar 4. Peta ZNT metode AHP}

\section{SIMPULAN}

Berdasarkan hasil penelitian pembuatan peta Zona Nilai Tanah dengan metode Analytical Hierarchy Process Kecamatan Sewon, Kabupaten Bantul, Provinsi D.I. Yogyakarta dapat disimpulkan bahwa:

1. Adapun dari perhitungan AHP diperoleh bobot paling berpengaruh terhadap nilai tanah adalah jalan arteri yaitu sebesar 0.395 dan bobot paling rendah adalah sekolah dasa dengan bobot sebesar 0.004. sehingga dapat disimpulkan bahwa zona disekitar jalan arteri mempunyai nilai tanah tinggi karena jalan arteri merupakan faktor penentu nilai tanah yang paling berpengaruh. Semakin tinggi bobot suatu zona yang diperoleh dari analisis spasial faktor penentu nilai tanah maka semakin tinggi nilai tanah tersebut.
2. Persebran Zona Nilai Tanah dengan NIR 250 ribu rupiah - 500 ribu pada peta Zona Nilai Tanah mengunakan metode AHP di kecamatan sewon menempati urutan terluas yaitu 1146.996 ha, sedangkan zona dengan luasan terkecil terdapat pada kelas zona antara 750 ribu - 1 juta rupiah dengan luasan 30.651 ha.

3. Perbedaan nilai tanah dari peta Zona Nilai Tanah BPN dan metode AHP paling signifikan terjadi pada area disektitar fasilitas umum dan sepanjang koridor jalan kolektor yang dekat dengan jalan arteri. Hal ini dikarenakan pada pembuatan zona awal peta ZNT BPN tidak memperhitungkan jarak dari pusat faktor penentu nilai tanah terhadap nilai tanah disekitarnya dan tidak memperhatikan tingkatan kelas jalan. 


\section{REKOMENDASI}

1. Penelitian tentang Zona Nilai Tanah dengan metode AHP selanjutnya akan lebih baik jika menggunakan data transaksi-jual terutama data dari pelaku properti secara langsung. Selain itu data sebaiknya menggunakan transaksi jual-beli terkini, sehingga nilai tanah yang diperoleh akan lebih mendekati nilai tanah yang sebenarnya.

2. Perlu penelitian yang lebih lanjut tentang parameter factor penentu nilai tanah di kecamatan sewon dengan metode lain untuk perbandingan hasil dengan yang telah dilakukan guna mendapatkan nilai tanah mendekati harga sebenarnya dengan lebih akurat lagi.

\section{DAFTAR PUSTAKA}

Achsin, M. 2011. Tesis : Penentuan Lokasi Pembangunan Perumahan, Penerapan Analytical Hierarchy Process (AHP) Di Kota Malang, Magister Ekonomomi Pembangunan, Universitas Gadjah Mada.

Amalia, Novita, dkk. 2015. " Pemetaan Zona Nilai Tanah Untuk Menentukan Nilai Jual Obyek Pajak (NJOP) Menggunakan Sistem Informasi Geografis Di Kecamatan Pedurungan, Kota Semarang. Jurnal UNDIP. ISSN : 2337-845X.

Ananta dan Supriyanto. 1999. Penelitian Tentang Sektor Informal. Jurnal ekonomi UGM. Yogyakarta

Anonim, 1994. PMNA No. 1 Tahun 1994 Tentang Ketentuan Pelaksanaan Keputusan Presiden RI No.55 Tahun 1993 Tentang Pengadaan Tanah Bagi Pelaksanaan Pembangunan Untuk Kepentingan Umum, Kementrian Agraria, Jakarta.

Anonim, 1999. Surat Edaran Direktorat Jenderal Pajak Nomor : SE55/PJ.6/1999 tanggal 31 Agustus 1999 Tetang Petujuk Teknis Analisis Penentuan Nilai Indikasi Rata-rata, Direktorat Jenderal Pajak, Jakarta.
Anonim, 2006. Surat Edaran Direktorat Jenderal Pajak Nomor : SE25/PJ.6/2006 tanggal 20 Juli 2006 Tentang Tata Cara Pembetukan/Penyempurnaan ZNT/NIR, Direktorat Jenderal Pajak, Jakarta.

Aronoff, Stan. 1989. Geographic Information System; A Management Perspective, Ottawa. WDL, Publications.

Berry, Brian J.L, 1984. "National Urbanization Policy in Developing Countries (Bertrand Renaud) in Economic Development And Cultural Change", Paper Review.

Chaizi, Nasucha. 1995. Politik Ekonomi Pertanahan dan Struktur Perpajakan Atas Tanah. Jakarta : PT. Kesaint Blanc Indah Co

Damayanti, Astrid dan Syah, Alfian. 2009. Penilaian Tanah Dengan Pendekatan Keruangan, Universitas Indonesia, Jakarta. Eckert, J. K., Gloudeinans and Almy R. 1990. Properti Appraisal and Assesment Administration. IAAO. Chicago. IIIinois.

Ernawati, Ririn. 2005. Skripsi : Studi Keandalan Luas persil Dalam Pendaftaran Tanah Sistematik di Perkotaan dan Pedesaan, Fakultas Teknik, Universitas Brawijaya, Malang.

Estimiyarti, R. (2012). Pemanfaatan Model Regres Dalam Pembuatan Peta ZNT, Sekolah Tinggi Pertanahan Nasional, Yogyakarta.Gardner, Howard. (2003). Kecerdasan Majemuk, Teori dalam Praktek. Interaksara: Jakarta.

Fakultas Ekonomi UGM, PPE dan BPN. 1994. Studi Tentag Sistem Penentuan Harga Tanah, Yogyakatra : Universitas Gadjah Mada

Hartono, M. (2008). "Penentuan Nilai Tanah Dengan Analisis Spasial, AHP dan Regresi Di Sekitar Wilayah Banjir 
Lumpur Sidoarjo Jawa Timur", Program Studi Magister Teknik Geodesi dan Geomatika Bidang Pengutamaan Administrasi Pertanahan-ITB, Bandung.

Hartati, Sri dan Nugroho, Adi. (2012). Sistem Pendukung Keputusan Berbasis AHP (Analytical Hierarchy Process) untuk Penentuan Kesesuaian Penggunaan Lahan (studi kasus : Kabupaten Semarang), Universitas Ahmad Dahlan, Yogyakarta Hermit, Herman. 2009. Cara Memperoleh Sertifikat Tanah, Mandar Maju, Bandung

Hidayati, Wahyu dan Harjanto, Budi. 2003. Konsep Dasar Penilaian Properti, BPFE, Yogyakarta.

Indradi, IG dan Subroto, Tullus. 2014. Kartografi. Sekolah Tinggi Pertanahan Kementrian Agraria dan Tata Ruang/ Badan Pertanahan Nasional, Yogyakarta.

Kurniati, Erna dan Rahardjo, Noorhadi. 2012. Evaluasi Metode Klasifikasi dalam Pembuatan Peta Kepadatan Penduduk DIY dengan Permukaan Statistik dan Uji Proporsi. Universitas Gadjah Mada, Yogyakarta.

Lazirosa, Presylia, 2002. Studi Kajian Nilai Lahan. Universitas Kristen Petra, Surabaya.

Lucky, Djuniardi. 1997. Skripsi : Studi Keandalan Luas Persil Dalam Pendaftaran Tanah Sistematis di Perkotaan dan Pedesaan, Bandung : Departemen Teknik Geodesi ITB Northam, Ray, M. 1975. Urban Geography. Newyork, London: Oregon State University John Wiley and Sons.

Perangin Effendi. 1994. Hukum Agraria Indonesia, Suatu Telaah Dari Sudut Pandang Praktisi Hukum. Jakarta: Raja Grafindo.

Prahasta, Eddy. 2009. Sistem Informasi Geografi : Konsep- Konsep Dasar
(Perspeksi Geodesi \& Geomatika). Bandung : Penerbit Informatika Bandung.

Prasetyo, Dwi Juli. 2014. Skripsi : Kajian Kerawanan Longsorlahan Menggunakan Metode Analytical Hierarchy Process dan Sistem Informasi Geografis di DAS Ijo Daerah Istimewa Yogyakarta. Yogyakarta: Fakultas Geografi UGM.

Saaty, Thomas L., 1990, Analytical Hierarchy Process, Theory, Methodology, Process and Application. Upper Sadle River : Prentice Hall.

Saaty, T Thomas L. 1991. Some Mathematical Concept of the Analytical Hierarchy Process. Behaviormatrika, 29.

Saaty, Thomas L. 1992. Multicriteria Decision Making. The Analytic Hierarchy Process. Pittsburgh. RWS Publications.

Saaty, Thomas L. 1993. Pengambilan Keputusan Bagi Para Pemimpin, Proses Hirarki Analitik untuk Pengambilan Keputusan dalam Situasi yang Kompleks. Setiono L, penerjemah; Peniwati K, editor. Jakarta: PT.Pustaka Binaman Pressindo. Terjemahan dari: Decision Making for Leaders The Analytical Hierarchy Process for Decisions in Complex World. Sadahiro, Yukio. 2006. Course \#716-26 Advanced Urban Analysis E. Lecture Title: Spatial Analysis using GIS - Associate professor of the Department of Urban. Japan: Engineering, University of Tokyo.

Sarah, Kurdinanto. 2004. Aspek Perumusan Nilai Tanah Sebagai Masukan Kebijaksanaan Tanah Perkotaan Bandung. Bandung : Program Studi Perencanaan Wilayah dan Kota FTSPITB. 
Standard Penilaian Indonesia. 2007. Penilaian Property, Kemenkeu

Triahtaphyllou E. 2005. The impact of aggregating benefit and cost criteria in four MCDA methods. Los Angeles : IEEE Transactions on Engineering Management (Volume: 52 , Issue: 2)

Waljiyanto dan Sumandi, Y. (2002), "Aplikasi Sistem Informasi Geografis Untuk Zonasi Nilai Tanah Studi Kasus
Kecamatan Pleret, Kabupaten Bantul”, Jurusan Teknik Geodesi-UGM, Yogyakarta.

Wedasana A.S., 2011, Tesis : Analisis Daerah Rawan Kecelakaan dan Penyusunan Database Berbasis Sistem Informasi Geografis (Studi Kasus Kota Denpasar), Tesis S-2, Program Magister Program Studi Teknik Sipil, Program Pascasarjana Universitas Udayana, Denpasar. 